\title{
TÜRK HUKUKUNDA TUTUKLULUKTA AZAMİ SÜRE
}

\author{
The Upper Limit of Arrest under Turkish Law
}

\section{Metin FEYZİOĞLU* Güneş OKUYUCU ERGÜN**}

\begin{abstract}
ÖZET
Tutuklama peşin bir ceza değil, bir koruma tedbiridir. Dolayısıyla, geçici olmak zorundadır. Tutuklamaya ancak kanunda aranan bütün koşullar gerçekleştiğinde ve başka bir tedbirle tutuklamadan beklenen sonuca ulaşılması mümkün olmadığında başvurulmalıdır. Ayrıca belirtmek gerekir ki kanunda tutukluluk için öngörülen süreler, azami sürelerdir. Kanunda öngörülen bu azami süreler henüz dolmamış olmasına rağmen, somut olayın koşullarında tutuklamanın şartları ortadan kalkmış yahut tutuklama ile ulaşılması beklenen amaca ulaşılmış ya da tutukluluk makul süreyi aşmış olabilir. Böyle bir durumda tutukluluğa derhal son verilmelidir.

* Prof. Dr., Ankara Barosu Avukatı, Ankara Hukuk Fakültesi Ceza ve Ceza Usulü Hukuku Anabilim Dalı Öğretim Üyesi (metin.feyzioglu@law.ankara.edu.tr).

** Dr., Ankara Hukuk Fakültesi Ceza ve Ceza Usulü Hukuku Anabilim Dalı Öğretim Elemanı(okuyucu@law.ankara.edu.tr).
\end{abstract}


Anahtar Sözcükler: Tutuklama, Tutuklama şartları, Şüpheden sanık yararlanır ilkesi, Suçsuzluk karinesi, İnsan hakları, Savunma hakkı

\begin{abstract}
Arrest is not an advance penalty but instead a protective measure. It thus must be of a temporary nature. Arrest should be utilized only if all of the conditions required under the law are fulfilled and the intended result to be achieved by arrest cannot be achieved by any other type of measure. It is also noteworthy that the time periods envisaged by the law for the arrest are the upper limits. In certain cases, even if such upper time limits have not yet been reached, the conditions for arrest may have ceased to exist, or the intended result to be achieved by arrest may have already been achieved, or the term of arrest may have exceeded a reasonable period of time. In such cases, the arrest should immediately be terminated.
\end{abstract}

Keywords: Arrest, Conditions for arrest, Beyond any doubt principle in criminal trial, Presumption of innocence, Human rights, Right to defense

\title{
SUNUŞ
}

Tutuklama, henüz kesin hükümle suçluluğu sabit olmadan şüpheli veya sanığın hürriyetini en ağır şekilde sınırlandırdığından hem anayasa ve kanunlarda hem de insan haklarına ilişkin uluslararası metinlerde sıkı koşullara bağlanmıştır. Çağdaş hukuk sistemlerinde tutuklama, bir ceza değil; ceza muhakemesinin amacına ulaşmasını sağlamak için başvurulan bir tedbirdir. Buna karşın; ceza muhakemesinin amacının sanığ 1 cezalandırmak olduğu eski devirlerdeki alışkanlığı sürdüren toplumlarda tutuklama, peşin bir ceza olarak değerlendirilmekte, tutukluluğun keyfi olması veya somut olayın koşullarında orantısız bulunması yahut makul süreyi aşması, ilkel düşüncelerin etkisiyle doğal karşılanmaktadır. 
Makalede tutuklamanın şartları hakkında kısaca bilgi verildikten sonra, sadece bir koruma tedbiri olduğu, bu nedenle geçici olması gerektiği açıklanacak; ardından tutukluluk bakımından azami sürelere ilişkin hukuki düzenlemeler incelenerek bu konuda çeşitli değerlendirmelerde bulunulacak; son olarak, tutuklulukta geçecek azami sürelerin dolmasının hukuki sonuçları tartışılacaktır.

\section{TUTUKLAMA CEZA DEĞIIL, KORUMA TEDBİRIDİR: BU NEDENLE GEÇİCIDIR}

1. Ceza Muhakemesi Kanunu'na (CMK) göre tutuklamanın temel şartı, şüpheli veya sanığın isnad konusu suç fiilini işlediği konusunda kuvvetli şüphe oluşmasına neden olan delillerin bulunmasıdır (CMK md. 100).

2. Ancak tutuklamanın bu temel şartına bakılarak, tutuklamanın peşin bir ceza olduğu sonucuna asla ulaşılamaz:

a. Çünkü Anayasa md. 38 ve Avrupa İnsan Hakları Sözleşmesi (AİHS) md. 6'da güvencesini bulan suçsuzluk karinesine göre hiç kimse suçlu olduğu kesin hükümle sabit olana kadar suçlu kabul edilemez.

b. İlk derece mahkemesi tarafından hakkında temyiz edilebilir (veya istinafa başvurulabilir) bir mahkûmiyet kararı verilen kişi dahi, mahkûmiyet hükmü kesinleşinceye kadar hükümlü sıfatını almaz; sanıklık sıfatı devam eder (CMK md. 2/1-b) ve suçsuzluk karinesinden yararlanır. Başka bir anlatımla ilk derece mahkemesi tarafindan verilen mahkûmiyet hükmü henüz kesinleşmeyen sanık, bu hüküm kesinleşmediği sürece suçlu kabul edilmez.

c. Ceza ve Güvenlik Tedbirlerinin İnfazı Hakkında Kanun'un 4. maddesinde yer alan "Mahkûmiyet hükümleri kesinleşmedikçe infaz olunmaz" hükmünün anayasal dayanağ 1 , suçsuzluk karinesidir. ${ }^{1}$

${ }^{1}$ Zira suçsuzluk karinesi, bir kişinin suçlu olarak nitelendirilebilmesi ve hakkında cezai müeyyidelerin uygulanabilmesi için, kesin hükümle mahkûm olmasını gerektirir (FEYZIOĞLU, Metin: "Suçsuzluk Karinesi: Kavram Hakkında Genel Bilgiler ve Avrupa İnsan Hakları Sözleşmesi", $A \ddot{U H} H F$, yıl: 1999, c. 48, sy. 1-4, ss. 135-163, s. 139; FEYZİOĞLU, Metin: Ceza Muhakemesinde Vicdani Kanaat, Ankara 2002, s. 192 
3. Şu halde şüpheli veya sanık hakkında tutuklama kararı verilebilmesi için "delillere dayanan kuvvetli şüphe"nin temel şart olarak aranmasının sebebi, tutuklamanın bir ceza olması değildir. ${ }^{2} \mathrm{Bu}$ şartın aranmasının sebebi, yargılama makamının, kişinin suçu kesin hükümle sabit olmadan önce hürriyetini en ağır şekilde kısıtlayan tutuklama kararını keyfi olarak vermemesini sağlamaktır. ${ }^{3}$ Buna göre, soruşturmada hâkim, kovuşturmada mahkeme o anki delil durumuna göre isnad konusu suç fiilini işlediğine dair kuvvetli şüphe bulunan kişiler dışındaki kişileri tutuklayamazlar. ${ }^{4}$ Örneğin, kamuoyunu yatıştırmak, suç işlemeyi planlayanları caydırmak, şüpheli veya sanığın can güvenliğini korumak, soruşturma veya kovuşturma organlarıyla işbirliği yapmasını, ifade vermesini, delillerin yerini göstermesini, suç ortağı olduğu ileri sürülen kişilerin saklandıkları yeri bildirmesini sağlamak gibi amaç ve gerekçelerle yargılama makamı tutuklama kararı veremez.

4. Tutuklama kararı verilmesi için kuvvetli şüphenin varlığı da yeterli değildir. Aynı zamanda tutuklama orantılı olmalı, şüpheli ya da sanığın kaçacağını veya delilleri karartacağını gösteren somut belirtiler bulunmalı ve adli kontrol uygulanarak tutuklama ile ulaşılmak istenen amaca ulaşılması mümkün olmamalıdır. ${ }^{5}$ Ancak konumuz tutuklamanın

vd.; KUNTER, Nurullah/YENISEY, Feridun/NUHOĞLU, Ayşe: Muhakeme Hukuku Dalı Olarak Ceza Muhakemesi Hukuku, İstanbul 2006, s. 25, 436-437).

${ }^{2}$ Tutuklamanın eskiden ve günümüzde eski zihniyetin etkisindeki insanlar ve toplumlarda cezalandırma olarak algılandığı; ancak artık bu anlayışın terk edildiği; tutuklamanın ceza olmadığ ; kesinleşmiş bir mahkûmiyet kararı ile suçlu olduğu belirlenmedikçe kimseyi cezalandırma hakkımızın bulunmadığı hakkında bkz. KUNTER/YENISEY/NUHOĞLU: s. 751-752. Tutuklamanın bir ceza olmadığına ilişkin olarak ayrıca bkz. ŞENTUNA, Mustafa Tarık: 5271 Sayılı Ceza Muhakemesi Kanununda Tutuklama ve Adli Kontrol, Ankara 2007, s. 34.

${ }^{3}$ CMK'ya göre, "Küçük bir belirti de tutuklama için yeterli olmayacak; kuvvetli suç şüphesinin varlığını gösteren olgular bulunacaktır. Bu suretle keyfi tutuklamaların önlenebilmesi için ciddi bir güvence getirilmiştir." (ÖZTÜRK, Bahri/ERDEM, Mustafa Ruhan: Uygulamalı Ceza Muhakemesi Hukuku, Ankara 2007, s. 555).

${ }^{4}$ AİHM'ne göre, suçun işlendiğine dair makul şüphe, tutuklamanın olmazsa olmaz (sine qua non) bir koşuludur (Bkz. Letellier/Fransa, Başvuru No. 12369/86, 26.6.1991).

5 KUNTER/YENISEY/NUHOĞLU: s. 758 vd.; ÖZTÜRK, Bahri/TEZCAN, Mahmut/ERDEM, Mustafa Ruhan/SIRMA, Özge/SAYGILAR, Yasemin F./ALAN, Esra: Nazari ve Uygulamal Ceza Muhakemesi Hukuku, Ankara 2009, s. 405 vd.; CENTEL, Nur/ZAFER, Hamide: Ceza Muhakemesi Hukuku, İstanbul 2008, s. 327 vd.; NUHOĞLU, Ayşe: "Koruma Tedbiri Olarak Tutuklama", (in) Ceza Muhakemesi 
şartlarının incelenmesini kapsamadığından burada bu kadar açıklama ile yetiniyoruz.

5. Tutuklama bir koruma tedbiri olduğu için, geçicidir. Geçicilikten kastımız şudur:

a. Tutuklama, şartları ortadan kalktığında sona erdirilmelidir.

b. Tutuklama, makul süreyi aşmamalıdır.

6. Tutuklamanın geçici olduğu benimsenmez ise, koruma tedbiri olmaktan çıkar ve ceza gibi uygulanır hale gelir. ${ }^{6}$

7. Tutukluluğun makul süreyi aşmaması, AİHS md. $5^{\text {'in emridir. }}{ }^{7}$

8. Tutuklulukta geçen sürenin makul olup olmadığı somut olayın şartlarına göre değerlendirilir. ${ }^{8}$ Bu nedenle "makul süre" kavramı kesinlik ifade etmemektedir.

Kanunun 3. Yllı, İstanbul 2009, ss. 175-191, s. 179-180; GAROFOLI, Vincenzo: Istituzioni di diritto processuale penale, Milano 2006, s. 228.

${ }^{6}$ Tutuklama, ceza değil, ceza muhakemesinin amacına ulaşmak için başvurulan bir araç; bir koruma tedbiridir (FEYZİĞLU, Metin: "Tutuklamaya Dair Uygulamada Görülen Bazı Sorunlar, Tesbitler, Değerlendirmeler”, (in) Prof. Dr. Ali Naim İnan'a Armağan, Ankara 2009, ss.1189-1193, s.1190). Zira suçsuzluk karinesi gereğince, tutuklama müeyyide niteliğinde olamaz (ÖZTÜRK vd.: Nazari ve Uygulamall, s. 401). Ancak tutuklama için aranan koşullar ortadan kalktığı halde şüpheli veya sanığın tutukluluk halinin devam ettirilmesi, söz konusu kurumun öne alınmış bir ceza olması sonucuna yol açar (ÖZTÜRK vd.: Nazari ve Uygulamall, s. 411). Gerçekten de uzun tutukluluk süreleri, delil yetersizliğinden beraat etme olanağı bulunan sanığın bu yolla cezalandırıldığı düşüncesini doğurabilir; bu nedenle hâkimler bakımından oyunu belli etme anlamı taşıyabileceği de savunulmuştur (bkz. CENTEL/ZAFER: s. 339).

${ }^{7}$ AİHS md. 5/3 uyarınca, “... yakalanan veya tutulu durumda bulunan herkes hemen bir yargıç veya adli görev yapmaya yasayla yetkili kılınmış diğer bir görevli önüne çıkarılır; kendisinin makul bir süre içinde yargılanmaya veya adli kovuşturma sırasında serbest bırakılmaya hakkı vardır."

${ }^{8}$ AİHM'e göre de tutuklulukta geçen sürenin makul olup olmadığı, her olayın somut özelliklerine göre değerlendirilmelidir (bkz. Wemhoff/Almanya, Başvuru No. 2122/64, 25.4.1968). Bununla beraber AİHM, çeşitli kararlarında makul süreye ilişkin bazı ölçütler de geliştirmiştir. Öncelikle, suç işlendiğine ilişkin makul şüphenin devam ediyor olması, tutukluluk süresinin uzatılması için tek başına yeterli değildir (bkz. Mansur/Türkiye, Başvuru No. 14-1994-461-542, 8.6.1995). Tutukluluk süresinin uzatılabilmesi için, suçun işlendiğine ilişkin makul şüpheye ilave olarak, özgürlüğün kısıtlamasını haklı kılacak "geçerli" ve "yeterli" gerekçelerin bulunması da gerekmektedir (bkz. Letellier/Fransa, Başvuru No. 12369/86, 26.6.1991). Yine AİHM'e göre, bir suçun cezasının ağır olması, söz konusu sanığın kaçma tehlikesini artıran bir 
9. Kanun koyucu, makul süre kavramının belirsizliğinden yola çıkarak, tutuklamada azami süreler kabul etmiştir. ${ }^{9}$ Söz konusu süreler, tutuklulukta geçirilecek sürenin makul sayılabilmesi için azami bir sınır olarak mütalaa edilmelidir. ${ }^{10}$ Kuşkusuz tutuklulukta makul süreye, somut olayın şartlarına göre azami süre dolmadan da ulaşılabilir. ${ }^{11}$

10. Aşağıda incelenecek bu süreler azami sürelerdir. Dolayısıyla, kanundaki azami süre dolmamış olsa dahi, tutuklama şartları ortadan kalktığında veya AİHS md. 5'te yer alan ve AİHM içtihadıyla şekillenen "makul süre" somut olayda aşıldığında tutuklamaya son verilmelidir.

unsur olarak kabul edilemez ve dolayısıyla bir suçun cezasının ağır olması tek başına o suçun sanığının tutukluluk halinin devamına karar verilmesi için yeterli bir gerekçe teşkil etmez (bkz. Mansur/Türkiye, Başvuru No. 14-1994-461-542, 8.6.1995). Bir başka AİHM kararında ise, isnad edilen suçun terör suçu olmasının tek başına tutukluluk halinin devamı için yeterli bir sebep olmadığı belirtilmiştir (Tomasi v. Fransa, Başvuru No. 12850/87, 27.8.1992). Söz konusu kararda, isnad edilen suçun cezasının ağır olmasının tutukluluk süresinin uzatılmasına gerekçe olamayacağı; terör olayının gerçekleştiği ilk günlerde kamu düzeninin zarar görme riskinin bulunduğunun varsayılmasının makul karşılanabileceği, ancak belirli bir süre sonra bu riskin ortadan kalktığının kabul edilmesi gerektiği ifade olunmuştur.

${ }^{9}$ Evvelce, tutukluluğun devamı konusunda makul süreler bulunmamasına karşın, sanığın makul sürede yargılanma hakkından dolayı 1992 yılında CMUK'da yapılan değişiklikle bu konuda azami süreler öngörüldüğüne ilişkin olarak bkz. KUNTER/YENISEY/NUHOĞLU: s. 775. Türkiye gibi diğer bazı devletler de AİHS'nin etkisiyle tutuklamada azami süreler kabul etmişlerdir. Örneğin İskoç hukukuna göre, sanığın işlediği suç ne kadar ağır olursa olsun ancak 110 gün tutuklu bırakılabilir. Bu süre savcının talebi ve yüksek mahkemenin kararıyla uzatılabilir. Avusturya Ceza Muhakemeleri Usulü Kanunu da 5 yıl hapis cezasını aşan suçlarla ilgili yargılamalarda azami 2 yıllık bir tutukluluk süresi öngörmüştür (Bkz. ÜNAL, Şeref: Avrupa İnsan Hakları Sözleşmesi, Ankara 1995, s. 157).

10 AİHM'e göre, tutuklulukta geçecek sürenin makul bir süre olması kuralına paralel olarak, tutuklu yargılanan sanığın davasının tutuksuz yargılananlara oranla daha çabuk sona erdirilmesini talep etme hakkı bulunmaktadır (bkz. Wemhoff/Almanya (Başvuru No. 2122/64, 25.4.1968).

${ }^{11}$ Nitekim AİHM, 09.01.2003 tarihli Shishkov kararında, 6 ay 3 haftalı tutuklama süresini AİHS m. 5/3'ün ihlali olarak değerlendirmiş; m. 5/3'ün belirli bir süreyi aşmayan gerekçesiz tutuklama kararlarını tolere edecek biçimde yorumlanamayacağına; yetkili merciin tutuklamanın her aşamasını, bu aşamanın kısa olup olmadığına bakmaksızın ikna edici biçimde gerekçelendirmek zorunda olduğuna karar vermiştir (Bkz. ÖZTÜRK vd.: Nazari ve Uygulamal,, s. 414). Tutuklamanın süreyle sınırlandırılmış olması, tek başına, AİHS'nin ihlalini engellemeyecektir (ÖZTÜRK vd.: Nazari ve Uygulamall, s. 415). 


\section{CEZA MUHAKEMESI KANUNU'NUN TUTUKLULUKTA AZAMİ SÜREYE İLIŞKIN DÜZENLEMELERİ \\ A. GENEL GÖREVLİ MAHKEMELERIN GÖREV ALANINA GIREN SUÇLAR AÇISINDAN}

1. $\mathrm{CMK}$, genel görevli mahkemeler açısından tutuklulukta azami süreleri 102. maddesinde düzenlemiştir.

2. Buna göre:

\section{"Tutuklulukta geçecek süre}

(1) (Değişik: 2006/5560) Ăgır ceza mahkemesinin görevine girmeyen işlerde tutukluluk süresi en çok bir yıldır. Ancak, bu süre, zorunlu hallerde gerekçeleri gösterilerek altı ay daha uzatılabilir.

(2) Ă̆ır ceza mahkemesinin görevine giren işlerde, tutukluluk süresi en çok iki ylldır. Bu süre, zorunlu hallerde, gerekçesi gösterilerek uzatılabilir; uzatma süresi toplam üç yll geçemez.

(3) Bu maddede öngörülen uzatma kararları, Cumhuriyet savcısının, şüpheli veya sanık ile müdafiinin görüşleri alındıktan sonra verilir."

3. Görüldüğü üzere CMK düzenlemesi ağır ceza mahkemelerinin görev alanına giren ve girmeyen suçlar ayrımını esas almaktadır.

4. 5235 say1lı Adli Yarg1 İlk Derece Mahkemeleri ile Bölge Adliye Mahkemelerinin Kuruluş, Görev ve Yetkileri Hakkında Kanun'un 12. maddesi uyarınca ${ }^{12}$ "Kanunların ayrıca görevli kıldı̆̆ hâller saklı

\footnotetext{
125235 sayılı Kanunun 12. maddesi, 31.032005 tarih ve 5328 sayılı kanunun 10. maddesi ve 11.05.2005 tarih ve 5348 sayılı kanunun 3. maddesi ile değiștirilmiștir. Maddenin söz konusu değişikliklerden önceki şekli şöyle idi: "Kanunların ayrıca görevli kıldı̆̆g haller sakl kalmak üzere, ağırlaştırılmıs müebbet hapis, müebbet hapis ve on yıldan fazla hapis cezalarını gerektiren suçlarla ilgili dava ve işlere bakmakla ağır ceza mahkemeleri görevlidir."

5328 sayılı kanunun 10 maddesi ile madde şu şekilde değiştirilmiştir: "Kanunların ayrıca görevli klldığı haller saklı kalmak üzere, Türk Ceza Kanununda yer alan yağma (m. 148), irtikâp (m. 250/1 ve 2), resmi belgede sahtecilik (m. 204), nitelikli dolandırıcılık (m. 158), hileli iflas (m. 161) suçları ile ağırlaştırılmış müebbet hapis, müebbet hapis ve on yıldan fazla hapis cezaların gerektiren suçlarla ilgili dava ve işlere bakmakla ă̆ır ceza mahkemeleri görevlidir."
} 
kalmak üzere, Türk Ceza Kanununda yer alan yağma (m. 148), irtikâp (m. 250/1 ve 2), resmi belgede sahtecilik (m. 204/2), nitelikli dolandırıcılık (m. 158), hileli iflâs (m. 161) suçları ile ağırlaştırılmış müebbet hapis, müebbet hapis ve on yıldan fazla hapis cezaların gerektiren suçlarla ilgili dava ve işlere bakmakla ağır ceza mahkemeleri görevlidir."

a. Madde, ağır ceza mahkemelerinin görevini ${ }^{13}$ suça göre ve cezaya göre olmak üzere iki farklı ölçüyü esas alarak belirlemiştir.

b. Buna göre, yağma (TCK md. 148), irtikap (TCK md. 250/1-2), resmi belgede sahtecilik (TCK md. 204), nitelikli dolandırıcılık (TCK md. 158) ve hileli iflas (TCK md. 161) suçlarında, bu suçlar için Kanun'da öngörülen cezalara bakılmaksızın ağır ceza mahkemeleri görevlidir.

c. Diğer yandan, suçun hangi suç olduğuna bakılmaksızın ağırlaştırılmış müebbed hapis, müebbed hapis ve on yıldan fazla hapis cezalarını gerektiren suçlarda da ağır ceza mahkemeleri görevlidir. Suçun cezası esas alınarak mahkemenin görevinin belirlendiği hallerde, 5235 sayılı Kanun'un 14. maddesine göre, ağırlaştırıcı ve hafifletici nedenler dikkate alınmaksızın kanunda yazan cezanın üst sınırına bakılacaktır.

5. Ağır ceza mahkemelerinin görevine girmeyen işlerde tutukluluk süresi 1 yıldır. Ancak zorunluluk halinde bu sürenin altı ay daha uzatılması mümkündür. Kanun, sürenin hesabında soruşturma ve

Daha sonra 12. maddede geçen "resmi belgede sahtecilik (m. 204)" ibaresi, 11.05.2005 tarih ve 5348 sayıll kanunun 3. maddesi ile "resmi belgede sahtecilik ( $m$. 204/2)" şeklinde değiştirilmiştir. 5348 sayılı kanun ile yapılan bu değişikliğin Anayasaya aykırı olduğu iddiası ile Anayasa Mahkemesine başvurulmuş, ancak Anayasa Mahkemesi, söz konusu itirazı 20.11.2008 tarih ve E. 2005/88, K. 2008/166 sayılı kararı ile reddetmiş ve söz konusu karar 26.02.2009 tarihli Resmi Gazetede yayımlanmıştır.

${ }^{13}$ Burada "görev" den kastedilen, madde itibariyle yetkidir. "Madde itibariyle yetki"nin anlamı için bkz. KUNTER/YENISEY/NUHOĞLU: s. 320; TOROSLU, Nevzat/FEYZİOĞLU, Metin: Ceza Muhakemesi Hukuku, Ankara 2009, s. 56; FOSCHINI, Gaetano: Sistema del diritto processuale penale, vol. I, Milano 1956, s. 315. 
kovuşturma ayrımı yapmamıştır. Dolayısıyla ağır ceza mahkemesinin görevine girmeyen işlerde, aynı işle ilgili soruşturmada tutuklu geçen süre de dahil olmak üzere en fazla 1 yıl 6 ay tutukluluk süresi mümkündür.

6. Ağır ceza mahkemelerinin görevine giren işlerde tutukluluk süresi 2 yıl olarak düzenlenmiştir. Zorunlu hallerde sürenin uzatılması mümkündür. Kanun uzatma süresini 3 yıl olarak belirlemiştir. Burada, normal süre ve uzatma süresi toplamının $\mathrm{m}$, yoksa yalnızca uzatma süresinin mi 3 yıl olduğu tartışllabilir. Aksini ileri sürenlerin varlığına rağmen ${ }^{14} 3$ yıllık süre yalnızca uzatma süresidir. ${ }^{15}$ Çünkü kanun açıkça "uzatma süresi” demektedir. Hükmün kanunlaşma süreci incelendiğinde, lafızdan yola çıkarak yaptığımız bu tesbitin doğru olduğu görülecektir. ${ }^{16}$ Ancak uzatma süresinin normal süreden uzun olarak düzenlenmesi, elbette kanun yapma tekniği açısından temel bir hatadır. Ayrıca toplam 5 y1llık tutuklama süresine izin veren bir düzenlemenin tutuklamanın bir koruma tedbiri oluşuyla ve geçici olması gerektiğiyle bağdaşmadığ ortadadir.

\section{B. ÖZEL GÖREVLİ AĞIR CEZA MAHKEMELERININN GÖREV ALANINA GIREN SUÇLAR AÇISINDAN}

1. CMK, 250. maddesinde, maddede belirtilen suçları yargılamakla ağır ceza mahkemelerinin görevlendirileceğini hükme bağlamıştır. Görevlendirme yetkisi Hakimler ve Savcılar Yüksek Kurulu'na aittir

2. Özel görevli ağır ceza mahkemelerinin görevine giren suçlar, CMK md. 250/1'in a, b ve c bentlerinde tahdidi olarak sayılmıştır. Özel

\footnotetext{
${ }^{14}$ İNCİ, Z. Özen: Bir Koruma Tedbiri Olarak Türk Ceza Muhakemesi Hukukunda Tutuklama, Ankara 2008, s. 144. Ağır cezalık suçlardaki bu beş yıllık sürenin AİHS'nin 5. maddesinde öngörülen makul süreyi aştığı, bu nedenle maddenin amaca uygun bir biçimde yorumlanarak uzatma dahil üç yıl şeklinde anlaşılmaya çalışılması gerektiği hakkında ayrıca bkz. KUNTER/YENISEY/NUHOĞLU: s. 776.

15 TOROSLU/FEYZİĞLU: s. 225; HAKERİ, Hakan/ÜNVER, Yener: Ceza Muhakemesi Hukuku, Temel Bilgiler, Ankara 2008, s. 181; ŞAHIN, Cumhur: Ceza Muhakemesi Hukuku, I, Ankara 2007, s. 231.

${ }^{16}$ Bkz. ÖZTÜRK/ERDEM: s. 563.
} 
kanunlarla da söz konusu mahkemenin görev alanına başka suçlar ilave olunabilir.

3. CMK md. $252 / 2$ uyarınca " 250 nci maddenin birinci fikrasinin (c) bendinde öngörülen suçlar bakımından, Kanunda öngörülen tutuklama süresi iki kat olarak uygulantr."

4. CMK md. 250/1-c'de sayılan suçlar şunlardır: TCK'nun 2. Kitabının 4. Kısmının Devletin Güvenliğine Karşı Suçlar başlıklı 4., Anayasal Düzene ve Bu Düzenin İşleyiş̧ine Karşı Suçlar başlıklı 5., Milli Savunmaya Karşı Suçlar Başlıklı 6. ve Devlet Sırlarına Karşı Suçlar ve Casusluk başlıklı 7. bölümlerinde yer alan suçlar.

5. TCK'nun yukarıda belirtilen bölümlerinde yer almalarına rağmen 305. maddede düzenlenen temel milli yararlara karşı faaliyette bulunmak için yarar sağlama, 318. maddede düzenlenen halkı askerlikten soğutma, 319. maddede düzenlenen askerleri itaatsizliğe teşvik, 323. maddede düzenlenen savaşta yalan haber yayma, 324. maddede düzenlenen seferberlikle ilgili görevin ihlali, 325. maddede düzenlenen düşmandan ünvan ve benzeri payeler kabulü suçu ve 332. maddede düzenlenen askeri yasak bölgelere girme suçu özel görevli ağır ceza mahkemelerinin görev kapsamının dışında tutulmuştur. Dolayısıyla bu suçlar açısından tutuklamada azami sürede özel bir düzenleme yoktur; genel hüküm uygulanir.

6. Özel görevli ağır ceza mahkemesinin yargıladığı suçun CMK md. 250/1-c'de sayılan (ve elbette kapsam dışında bırakılmayan) bir suç olmas1 durumunda, tutuklulukta azami süre, CMK md. 102/2'deki sürelerin iki katı olacaktır. Bu durumda normal süre 4 yıl, uzatma süresi 6 yıl, toplam süre ise 10 yıldır.

7. Kanunun, tutuklamanın toplam 10 yıla kadar uzayabileceğini peşinen kabul eden bir hüküm sevketmesi, kabullenillenmek; insan haklarıla ve tutuklamanın koruma tedbiri oluşuyla bağdaştırmak mümkün değildir. 
8. Yukarıda da açıklandığı üzere, AİHS md. 5 uyarınca tutuklama makul süreyi aşamaz. Makul süre kavramı kesin olmadığ 1 için, kanunkoyucu, temel hakların daha güçlü şekilde korunmasını amaçlayarak tutuklulukta azami süreler öngörmüştür. Suçlu olduğu kesin hükümle sabit olmadığına göre, suçlu kabul edilmeyen bir kişinin 10 yıl tutuklu kalabileceğini peşinen kabul eden bu düzenlemenin temel hakları koruma amacı taşımadığı açıktır. Bu düzenleme, olsa olsa, Anayasa gereği suçlu kabul edilmeyen bir kişinin 10 yıl süreyle tutuklu kalmasına neden olan kararları veren yargılama makamı mensuplarının hukuki ve cezai sorumluluklardan korunmasına hizmet eder. Buna bağlı olarak, hiç azami süre olmaması durumunda tutuklamanın geçici olduğundan yola çıkarak tutukluluk halini mümkün olan en k1sa sürede bitirmesi gerektiğinin bilincinde olan bir hâkim, kanunkoyucunun 10 y1la kadar tutukluluğun devamına izin vermesinden olumsuz etkilenebilir.

9. Özel görevli ağır ceza mahkemesinin görev alanına giren suçlarda tutuklulukta azami süreyi düzenleyen 2. fikranın yer aldığı CMK md. 252'nin kenar başlığ "kovuşturma"dır. Burada tartışılması gereken husus, CMK md. 252/2'nin uygulamasının kovuşturma evresiyle sınırlı olup olmadığıdır.

10. Aksi kanunda açıkça yazmadığı sürece maddelerin kenar başlıkları madde metninden sayılmazlar. ${ }^{17}$ Ancak, bağlayıcı olmamakla birlikte, kenar başlıkların maddenin yorumu sırasında yol göstermesi mümkündür.

11. CMK md. 252/2'nin metninde kovuşturma ve soruşturma ayrımı yapılmamış, genel bir ifade kullanılmıştır. Maddenin atıf yaptığı kanun CMK olup, ağır ceza mahkemesinin görevine giren işlerde tutuklulukta azami sürelerin düzenlendiği CMK md. 102/2'de de soruşturma ve kovuşturma ayrımı yoktur. Bu itibarla, kanaatimizce, maddenin kenar

\footnotetext{
${ }^{17}$ ANTOLISEI, Francesco: Manuale di diritto penale, parte speciale, vol. I, Milano 1999, s. 26. Aksi yönde bkz. TOROSLU, Nevzat: Cürümlerin Tasnifi Bakımından Suçun Hukuki Konusu, Ankara 1970, s. 215-216.
} 
başlığına rağmen 2. fikra hükmü soruşturma evresini de kapsar şekilde yorumlanmalıdır.

\section{UZATMA USULÜ}

1. CMK md. $102 / 1$ ve 2 'de, zorunlu hallerde sürenin gerekçe gösterilerek uzatılabileceği yazılıdır. Uzatma süreleri, yukarıda açıklandığı üzere, ilgili fikralarda hükme bağlanmıştır.

2. Görüldüğü üzere CMK, uzatma için, zorunluluk bulunmasını ve bu zorunluluğun gerekçede gösterilmesini şart koşmaktadır. Zorunluluğun ne zaman söz konusunu olacağını ise kanun belirtmemiştir. $\mathrm{Bu}$, keyfiliğe yol açması muhtemel olan bir eksikliktir.

3. Bu noktada, CMK md. $102 / 1$ ve 2 uyarınca verilen uzatma kararlarının gerekçesi ile CMK md. 108 uyarınca soruşturma ve kovuşturma süresince düzenli olarak yapılan incelemeler sonucunda verilen tutukluluğun devamı kararlarının gerekçesi arasında ne fark olduğu incelenmelidir.

a. Soruşturma evresinde, şüpheli tutukevinde bulunduğu süre içerisinde en geç otuz günde bir sulh ceza hakimi, tutukluluk halinin devamının gerekip gerekmediği konusunda bir karar vermek zorundadır (CMK md. 108/1).

b. Kovuşturma evresinde ise, tutukevindeki sanığın tutukluluk halinin devam edip etmeyeceğine duruşmanın her oturumunda ve en geç otuz günde bir, mahkeme veya hâkim tarafindan karar verilir (CMK md. $108 / 2)^{18}$

\footnotetext{
${ }^{18}$ Kovuşturma evresinde tutuklama kararı mahkeme tarafindan verilir (CMK md. 101). Tutukluluk halinin incelenip sanığın tahliyesine karar verilmesi için, kararda açıkça ifade edilsin veya edilmesin yürürlükteki tutuklama kararının geri alınması gereklidir. Başka bir anlatımla sanığın tahliyesine karar veren yargılama makamı, önce tutuklama kararını geri almakta, ardından, hakkındaki tutuklama kararını kaldırdığı sanığı tahliye etmektedir ( KUNTER/YENISEY/NUHOĞLU: s. 778-779) Kanunda aksi açıķ̧a yazılı olmadığ1 veya durumdan açıkça anlaşılmadığı sürece, adli işlemin geri alınması, o adli işlemi yapan makam tarafından gerçekleştirilmelidir. Öyleyse kovuşturma evresinde tutuklama kararını geri alarak sanığı tahliye etme yetkisi kural olarak mahkemeye aittir. Heyet halinde karar veren bir mahkeme söz konusu olduğunda, tutuklama kararı, heyet
} 
c. Suçluluğu hakkında delillere dayanan kuvvetli şüphe bulunan şüpheli veya sanığın, tutuklanmadığı takdirde delilleri karartacağını veya kaçacağını gösteren somut olgular bulunmalı ve bu kaçma ya da delilleri karartma tehlikesi adli kontrol tedbirleri uygulanarak önlenemeyecek olmalıdır. Yani ceza muhakemesinde tutuklamaya son çare olarak başvurulmaktadır. Doktrinde tutuklamanın zorunlu haksızlık olarak nitelendirilmesi bu sebepledir ${ }^{19}$. Burada "zorunlu" kelimesiyle, tutuklamanın uygulanması zorunlu bir tedbir olduğunu değil, ancak zorunlu kalındığında uygulanması gereken bir tedbir olduğunu kastediyoruz.

d. Tutukluluk halinin devamına karar verilebilmesi için tutuklama şartlarının devam ediyor olması ve azami sürenin dolmamış bulunması gereklidir.

e. Buraya kadarki açıklamalarımızı toparlayalım. Kanundaki tutuklama şartları dikkatle incelendiğinde, tutuklamaya ancak zorunlu kalınması durumunda başvurulabileceği görülmektedir. Şöyle ki;

i. Tutukluluk halinin devamı kararı verilmesi, tutuklama şartlarının varlığının devamına ve azami sürenin dolmamış olmasına bağlıdır.

ii. Öyleyse tutukluluk halinin devamına karar verilebilmesi için, tutukluluk halinin devamında yukarıda açıklandığı anlamda zorunluluk bulunması gereklidir.

tarafindan verilir. Şu halde mahkeme tarafindan (kararın mahkeme makamı kararı olabilmesi için heyet halinde karar veren mahkemelerde, kararın mahkeme heyetince verilmiş olması gereklidir) verilen bir tutuklama kararının incelenerek geri alınması ve sanığın tahliyesi için kural olarak yine mahkemece karar verilmelidir. CMK md. $108 / 3$ 'te ise hem hâkimden hem mahkemeden söz edilmektedir. Heyet halinde toplanıp karar veren bir mahkeme naip hâkimle duruşma yapamayacağına veya duruşma sırasında yalnızca başkan ya da bir üye tarafından tutukluluk hali incelenemeyeceğine göre, tutukluluk halinin kovuşturma evresinde "hâkimlik makamı"nca incelenmesi sadece oturum aralarında söz konusu olabilir. Ancak oturum arasında heyet halinde görev yapan mahkemenin tek hâkimle karar verebilmesi için heyetin toplanmasının imkansız olması şartı aranmalıdır. Aksi halde CMK md. 108/3'teki karar verme yetkisinin keyfi bir şekilde bazen hâkim bazen mahkeme tarafından kullanılmasına yol açılır.

${ }^{19}$ ÖZGEN, Eralp: Ceza ve Ceza Muhakeme Hukuku Bilgisi, Eskişehir 1988, s. 165. Tutuklamanın "zorunlu kötülük" olarak nitelendirilmesine ilişkin olarak ayrıca bkz. CENTEL, Nur: Ceza Muhakemesi Hukukunda Tutuklama ve Yakalama, İstanbul 1992, s. 7. 
iii. $\mathrm{Bu}$ durumda, azami sürenin uzatılması için kanunun aradığ 1 "zorunlu hal", tutuklama şartlarının varlığını devam ettiriyor olması değildir. Çünkü yargılama makamı tutuklama şartlarının varlığını devam ettirip ettirmediğini zaten düzenli olarak incelemekte ve tutukluluk halinin devamına ilişkin kararının gerekçesinde tutuklama şartlarının devam ettiği sonucuna neden ve nasıl ulaştığını açıklamaktadır.

iv. Burada kastettiğimiz "gerekçe", yasak savmak kabilinden yazılan "suçun vasıf mahiyeti", "delil durumu", "tüm dosya kapsamı" gibi içi boş ifadeler değildir. ${ }^{20}$ Anayasanın, CMK'nun, AİHS'nin ve AİHM'nin aradığı anlamda somut gerekçedir. Gerekçesiz tutuklama kararı veya tutukluluk halinin devamı kararı vermek büyük bir keyfiliktir. Böyle bir keyfilik, soruşturulan veya kovuşturulan suç ile ihlal edildiği ileri sürülen kamu düzeninin bir kez de yargılama makamınca ihlal edilmesi anlamına gelir. ${ }^{21}$ İş çokluğu, gerekçesiz tutuklama kararları veya tutukluluk halinin devamı kararları verilmesinin mazereti olamaz. Hürriyetin keyfi k1sitlanması, mazeret kabul etmez.

v. Kanunun, azami sürenin uzatılması için $\operatorname{aradığ~}$ "zorunlu hal", kanaatimizce, soruşturma veya kovuşturmanın çok kapsamlı olması nedeniyle delillerin toplanmasının tamamlanamamasıdır. ${ }^{22}$

4. Uzatma kararı normal sürenin sonunda verilmelidir. Kanun aylık veya yıllık uzatmalardan söz etmediğine göre, yargılama makamının

20 AİHM'nin Tandoğan/Türkiye kararında (Başvuru No: 9244/02, 20.9.2007), tutukluluk halinin sürdüğ̈̈ 6 y1l 10 aylık süre boyunca "yerel mahkemelerin "suçun niteliği, delil durumu ve gözaltı süresi gözönüne alınarak” gibi benzer ve klişeleşmiş terimler kullanarak başvuranın tutuklu yargılanma süresini uzattı̆̆ $l$ ” belirtilmektedir. Aynı yönde bkz. Atıc1/Türkiye, Başvuru No. 19735/02, 10.5.2007; Dereci/Türkiye, Başvuru No. 77845/01, 4.5.2005; Taciroğlu/Türkiye, Başvuru No. 25324/02, 2.2.2006).

21 Gerekçe yargılamanın adil olduğunu gösteren en önemli belgedir ve dolayısıyla CMK'da bunun zorunlu kılınmış olması son derece yerindedir (FEYZİĞLU: "Tutuklama...", s. 1190). Ancak yargi erki kapsamındaki yetkilerini kullanan kamu görevlileri ceza muhakemesi kurallarını ihlal ederlerse, kamu düzeni, en az soruşturma ve kovuşturma konusu suçun verdiği zarar kadar zarar görür (bkz. FEYZİOĞLU, Metin: "Korkuya Sevk Etmemeli", Cumhuriyet Gazetesi, 22.01.2009, s. 7).

${ }^{22}$ Nitekim mülga CMUK'nun tutuklulukta azami süreleri düzenleyen 110. maddesinde “soruşturmanın veya yargılamanın özel zorluğu veya geniş kapsamlı olması"ndan söz edilmekteydi. 
kanundaki uzatma süresinin tamamını kapsayacak şekilde uzatma kararı vermesi mümkündür. Ancak azami süre aşılmamak kaydıyla kısım kısım uzatma kararı verilmesinde bir engel yoktur. Buna göre örneğin ağır ceza mahkemesi zorunluluk nedeniyle tutukluluk süresinin uzatılmasını öngören kararlarını 6 aylık periyotlarla vermeyi uygun görebilir. Esasen kanunun çok uzun tutukluluk süresine izin verdiği hallerde yargılama makamları zorunluluk halini daha titiz değerlendirebilmek için kanaatimizce bu şekilde bir uygulamayı tercih etmelidirler. Elbette uzatma kararlarının, tutukluluk halinin en geç otuz günde bir incelenmesi zorunluluğunu (CMK md. 108) ortadan kaldırması söz konusu değildir; bu zorunluluk uzatma kararından sonra da devam eder.

\section{5320 SAYILI CEZA MUHAKEMESI KANUNUNUN YÜRÜRLÜK VE UYGULAMA ŞEKLİ HAKKINDAKİ KANUNDAKİ DÜZENLEME}

1. 5320 say1lı Kanun'un $12 / 1$. maddesi ${ }^{23}$ aynen şöyledir:

“Ceza Muhakemesi Kanununun 102 nci maddesi, aynı Kanunun 250 nci maddesinin birinci fikrasının (c) bendinde yazılı suçlar ile ağır ceza mahkemesinin görev alanına giren suçlar bakımından, 31 Aralı 2010 tarihinde yürürlüğe girer. Bu süre zarfinda 1412 sayll Ceza Muhakemeleri Usulü Kanununun 110 uncu maddesinin uygulanmasina devam olunur."

2. 5320 say1l Kanun'un 12/1. maddesi uyarınca, CMK md. 250/1c'de sayılan suçlar ile ağır ceza mahkemesinin görev alanına giren suçlar açısından CMK md. 102, 31 Aralık 2010 tarihinden itibaren uygulanmaya

\footnotetext{
${ }^{23} 5320$ sayılı kanunun 12. maddesinin 1. fikrası 11.05.2005 tarih ve 5347 sayılı kanun ve sonra 20.02.2008 tarih ve 5739 sayılı kanun ile değiştirilmiştir. 5347 sayılı kanun ile değiştirilmeden önce, söz konusu fikrada CMK m. 102'nin yürürlüğe giriş tarihinin ertelenmesi kapsamında sadece CMK m. 250/1-c'de yazılı suçlar belirtilmişken, anılına değişiklikle birlikte fikraya "ile ağır ceza mahkemesinin görev alanına giren suçlar" ibaresi de eklenmiş ve hüküm, CMK m. 102'nin, CMK m. 250/1-c'de yer alan suçlar ile ağır ceza mahkemesinin görev alanına giren suçlar bakımından 1 Nisan 2008'de yürürlüğe gireceği şeklini almıştı. Daha sonra söz konusu tarih, $\underline{\mathbf{5 7 3 9} \text { sayılı kanun ile }}$ 31 Aralık 2010 olarak değiștirilmiștir.
} 
başlanacaktır. 31 Aralık 2010 tarihine kadar mülga 1412 sayılı CMUK'nun 110. maddesinin uygulanmasina devam edilecektir.

3. Maddenin ilk halinde yalnızca CMK md. 250/1-c'de sayılan suçlara atıf yapılmış iken, 5347 sayılı Kanunla ağır ceza mahkemesinin görev alanına giren suçlar da hükme eklenmiştir. Bu eklemeden sonra, CMK md. 250/1-c'ye yapılan atıf anlamsız kalmıştır. Çünkü özel görevli ağır ceza mahkemesi de bir ağır ceza mahkemesidir. Dolayısıyla, "ağır ceza mahkemesinin görev alanına giren suçlar" ibaresinin maddeye eklenmesiyle birlikte CMK md. 250/1-a ve b'de sayılan suçlar da geçici olarak CMK md. 102'nin kapsamı dışında kalmıştır.

4. 5320 sayılı Kanun'un "yürürlüğe girme" tabirini kullanması doğru değildir. Çünkü bir kanun maddesi ya yürürlüktedir ya değildir. Kanunun belirli suçlar açısından yürürlüğe girmesi, belirli suçlar açısından girmemesi olmaz. Kanunda, "31 Aralık 2010 tarihinde yürürlüğe girer" yerine, "31 Aralık 2010 tarihinde uygulanmaya başlanır" denilmeliydi. Aynı şekilde bir kanun ya yürürlükten kaldırılmıştır ya kaldırılmamıştır. 5320 sayılı Kanun'un 18/1-a maddesi, 1412 sayılı CMUK'nu yürürlükten kaldırmıştır. Aynı Kanun'un 12/1. maddesi ise, yürürlükten kaldırılan CMUK'nun 110. maddesinin belirli suçlar açısından uygulanmaya devam edileceğinden söz etmektedir. 5320 sayılı Kanun'un bu çözüm yöntemi, kanun yapma tekniği açısından yanlıştır. Kanun, yürürlükten kaldırdığı bir kanunun yürürlükten kaldırdığı bir maddesinin uygulanmasına devam edileceğini hükme bağlamak yerine, uygulanmasına devam edilmesini istediği CMUK maddesini aynen tekrarlamak suretiyle geçiş dönemini düzenlemeliydi.

5. 5320 sayılı Kanun md. $12 / 1$ ağır ceza mahkemesinin görevine girmeyen suçlara atıf yapmadığı için, CMK md. 102/1, CMK'nun yürürlüğe girmesiyle birlikte uygulanmaya başlanmıştır. Uygulanması ertelenen hüküm, CMK md. 102/2'dir. İster genel görevli olsun ister özel görevli olsun ağır ceza mahkemesinin görevine giren suçlar açısından 31 Aralık 2010 tarihine kadar mülga CMUK'nun 110. maddesi uygulanmaya devam edilecektir. 
6. Şu halde bir suç 5235 sayılı Kanun'un 12. maddesine göre genel görevli veya CMK'nun 250. maddesine göre özel görevli ağır ceza mahkemesinin görevine giriyorsa CMK md. 102/2 değil, mülga CMUK md. 110 uygulanacaktır. Ağır ceza mahkemesinin özel kanun hükümleriyle görevlendirildiği diğer suçlar açısından da bu düzenleme geçerlidir.

7. 1412 sayılı CMUK madde 110 aynen şöyledir:

"Hazırlık soruşturmasinda tutukluluk süresi azamî altı aydır. Kamu davasının açılması halinde bu süre hazırlık soruşturmasında tutuklulukta geçen süre dahil iki yılı geçemez.

Soruşturmanin veya yargllamanin özel zorluğu veya geniş kapsamlı olmast sebebiyle yukartda belirtilen sürelerin sonunda kamu davast açılamamış veya hüküm tesis edilememiş ise, soruşturma konusu fiilin kanunda belirtilen cezasının alt sınırı yedi seneye kadar hürriyeti bağlayıcı cezayl gerektiren suçlarda tutuklama kararı kaldırılır. Yedi sene ve daha fazla hürriyeti bağlayıcı cezaları gerektiren suçlarda tutuklama sebebine, delillerin durumuna ve sanı̆̆ın şahsî hallerine göre tutukluluk halinin devamina veya sona erdirilmesine veya uygun görülecek nakdî kefaleti vermesi şartıyla sanığın tahliyesine karar verilebilir."

8. CMUK md. 110 tutuklulukta azami süreyi, hazırlık soruşturması ve dava açıldıktan sonra olmak üzere iki aşamalı olarak düzenlemiştir. CMK hazırlık soruşturması ve son soruşturma evrelerini kaldırmış, yerine soruşturma ve kovuşturma kavramlarını getirmiştir. Ancak bu durum, CMUK md. 110'un uygulanması açısından bir sorun teşkil etmemektedir. CMUK md. 110'daki hazırlık soruşturması tabiri, soruşturma olarak anlaşılacaktır.

9. Buna göre soruşturma evresinde tutuklulukta azami süre 6 aydır. Kovuşturmada ise, soruşturmada tutuklu geçirilen süre dahil olmak üzere azami süre 2 yıldır (CMUK md. 110/1).

10. CMUK md. 110/2, isnad konusu fiilin kanunda belirtilen cezasının alt sınırının 7 seneye kadar hürriyeti bağlayıcı ceza olması 
durumu ile alt sınırının 7 sene ve daha fazla hürriyeti bağlayıcı ceza olması durumunu birbirinden ayırmış ve şöyle bir düzenleme getirmiştir $^{24}$ :

a. İsnad konusu fiilin kanunda belirtilen cezasının alt sınırı 7 seneye kadar hürriyeti bağlayıcı ceza ise, CMUK md. 110/1 uygulanır. Yani alt sınırı 7 seneye kadar hürriyeti bağlayıcı ceza gerektiren suçlarda tutuklulukta azami süre soruşturma evresinde 6 ay, kovuşturma evresinde soruşturma evresinde tutuklu kalınan süre dahil 2 yıldır. Bu süre herhangi bir uzatmaya tabi değildir. Hükümde "soruşturmanın veya yargılamanın özel zorluğu veya genis kapsaml olmast sebebiyle yukarıda belirtilen sürelerin sonunda kamu davası açılamamış veya hüküm tesis edilememiş ise" şeklinde bir açıklamaya yer verilmesinin hükmün uygulamasını etkileyen herhangi bir anlamı yoktur. Çünkü ne olursa olsun sonuçta, yani 1. fikrada yazılı süreler dolduğunda, tutuklama kararının kaldırılacağı açıkça hükme bağlanmıştır.

b. İsnad konusu fiilin kanunda belirtilen cezasının alt sınırı 7 sene ve daha fazla hürriyeti bağlayıcı ceza ise, tutuklulukta azami bir süre yoktur. Hükümde tutuklama sebebinden, delillerin durumundan, sanığın şahsi hallerinden söz edilmesi herhangi bir anlam ifade etmemektedir. Çünkü yargılama makamının en fazla 30 günlük sürelerle yaptığ 1 tutukluluk hali incelemelerinde bu hususlar zaten dikkate alınmak zorundadır.

11. CMUK md. 110'un CMK yürürlüğe girdikten sonra -31 Aralık 2010 tarihine kadar- uygulanmasinda dikkat edilmesi gereken husus, soruşturma veya kovuşturma konusu suçun ağır ceza mahkemesinin görevine girip girmediğidir. Suç ağır ceza mahkemesinin görevine girmiyor ise CMK md. 102/1, ağır ceza mahkemesinin görevine giriyor ise CMUK md. 110/2 uygulanacaktır.

${ }^{24}$ Maddede 7 senenin ölçü olarak belirlenmesinin herhangi bir dayanağı yoktur (Bkz. ÖZTÜRK, Bahri /ERDEM, Mustafa Ruhan /ÖZBEK, Veli Özer: Uygulamalı Ceza Muhakemesi Hukuku, Ankara 1999, s. 648-649). 
12. Soruşturma veya kovuşturma konusu suçun ağır ceza mahkemesinin görevine girdiği tesbit edildikten sonra, suçun kanunda yazılı cezasının alt sınırına bakılacaktır:

a. Cezanın alt sınırı 7 seneye kadar hürriyeti bağlayıcı ceza ise, soruşturma evresinde azami tutukluluk süresi 6 aydır. 6 aylık bu süre hiçbir uzatmaya tabi değildir.

b. Cezanın alt sınırı 7 sene ve daha fazla hürriyeti bağlayıcı ceza ise, tutuklulukta azami süre yoktur.

13. Buna göre, 5235 sayılı Kanun'un 12. maddesi uyarınca ağır ceza mahkemesinin görevine giren yağma (TCK md. 148), irtikap (TCK md. 250/1-2), resmi belgede sahtecilik (TCK md. 204/2), nitelikli dolandırıcılık (TCK md. 158) ve hileli iflas (TCK md. 161) suçlarının kanunda yazılı cezalarının alt sınırı 7 seneden az hapis cezası olduğu için CMUK md. 110/2'nin 1. cümlesinin göndermesiyle CMUK md. 110/1 uygulanacaktır.

14. Yukarıda açıklandığı üzere ağırlaştırılmış müebbed, müebbed ve 10 yıldan fazla hapis cezasını gerektiren suçlar ağır ceza mahkemesinin görevine girer. Mahkemelerin görevleri belirlenirken kanunda yazılı cezanın ölçü olarak kullanıldığı hallerde 5235 sayılı Kanun'un 14. maddesi uyarınca cezanın üst sınırı esas alınır. Bu sebeple mevzuatımızda, ağır ceza mahkemesinin görevine girmekle birlikte alt sınırı 7 senenin altında hapis cezası olan pek çok suç vardır. Örneğin TCK md. 85/2'de düzenlenen taksirli davranışla ölüme sebep olma suçunun cezasının üst sınırı 15 yıl, alt sınırı 2 yıldır. TCK md. 94'teki işkence suçunun cezası 3 yıldan 12 yıla kadar hapistir. TCK md. 235 'teki ihaleye fesat karıştırma suçunun ve TCK md. 247'deki zimmet suçunun cezaları 5 yıldan 12 yıla kadar hapistir. TCK md. 252'deki rüşvet suçunun cezası 4 yıldan 12 yıla kadar hapistir. Bu suçlarla ilgili yargılama yapma görevi ağır ceza mahkemesine ait olduğundan bu suçların soruşturulması ve kovuşturulması sırasında tutuklananlar 
hakkında CMUK md. 110/2'nin 1. cümlesinin göndermesiyle CMUK md. 110/1'deki azami süreler uygulama alanı bulacaktır.

15. CMK md. 250 'de sayılan suçları yargılamakla görevli ağır ceza mahkemesinin görevine giren suçların da önemli bir kısmı, alt sınırı 7 senenin altında hapis cezası gerektiren suçlardır. Örneğin, CMK md. 250/1-a uyarınca özel görevli ağır ceza mahkemesinin görevine giren örgüt faaliyeti çerçevesinde işlenen suçtan kaynaklanan malvarlı̆̆ının değerini aklama suçunun cezasının alt sınırı TCK md. 282/1 ve 3 uyarınca 4 yıl hapistir. CMK md. 250/1-b uyarınca, haksız ekonomik çıkar sağlamak amacıyla kurulmuş olmak kaydıyla özel görevli ağır ceza mahkemesinin görevine giren suç işlemek için örgüt kurma ve örgüte üye olma suçunda TCK md. 220'nin alt sınır olarak öngördüğü cezalar 1 ila 3 yıl arasındadır. CMK md. 250/1-c uyarınca özel görevli ağır ceza mahkemesinin görevine giren TCK md. 307/2'deki taksirli davranışla askeri tesisleri tahribe sebep olma suçunda cezanın alt sınırı 1 yıl hapistir. Demek ki bu suçlarda tutuklulukta azami süre, CMUK md. 110/1 uyarınca soruşturmada 6 ay, kovuşturmada ise soruşturmada tutuklu geçirilen süre dahil olmak üzere toplam 2 yıldır.

16. Daha önce açıkladığımız üzere $C M K$ md. $252 / 2$ uyarınca $C M K$ md. 250/1-c maddesinde sayılan suçlarda "Kanunda öngörülen tutuklama süresi iki kat olarak uygulanır."

a. Hükümde sözü edilen "Kanun”, kuşkusuz CMK'dır. Nitekim kanun kelimesinin başharfi büyük yazılmıştı;; çünkü kanun kelimesiyle özel isim olan Ceza Muhakemesi Kanunu kastolunmaktadır. CMK'nun ağır ceza mahkemelerinin görev alanına giren suçlarda tutuklukta azami süreyi belirleyen 102/2. maddesi hükmü uygulamaya girmemiştir.

b. Acaba CMK md. 252/2'nin CMK md. 102/2'ye yaptığı bu gönderme, CMUK md. 110/1'deki sürenin de iki kat uygulanmasını gerektirir mi? Buna göre örneğin TCK md. 307/1'de yer alan ve alt sınırı 6 yıl hapis cezası gerektiren askeri tesisleri kasten tahrip suçunda 
tutuklulukta azami süre CMUK md. 110/1 uyarınca 6 ay ve 2 yıl midır, yoksa bu sürelerin iki katı olan 12 ay ve 4 yıl mıdır?

c. Burada, yürürlükten kalkmış bir kanuna, o kanun yürürlükten kalkmadan önce diğer bir kanunla yapılan bir gönderme söz konusu değildir. Başka bir anlatımla yürürlükten kalkmış olan kanuna başka kanunlarca yapılan göndermelerin, o kanunu yürürlükten kaldıran yeni kanuna yapılmış gibi kabul edilmesi durumu yoktur. Buradaki durum, yeni kanunun yine kendi içindeki bir maddeye gönderme yapması ve fakat gönderme yapılan maddenin uygulanmasının ertelenmiş olmasıdır.

d. CMK md. 252/2'nin CMK dişındaki bir kanunda yer alan tutukluluk süreleriyle ilgili olarak da uygulanması, kıyas yönteminin uygulanması yoluyla olabilir. Oysa ceza muhakemesi hukukunda kıyas yalnızca kural hükümlerin uygulanması sırasında başvurulabilecek bir yöntemdir. CMK md. 252/2 kural değil, istisnai bir hükümdür. Çünkü hukuk devletinde kişi hürriyeti kuraldır; kişi hürriyetini sınırlayan hükümler istisnaidir. Bu nedenle CMK md. 252/2'nin hükmü, CMK md. 102/2'nin uygulanmasına başlanıncaya (31 Aralık 2010'a) kadar uygulama alanı bulmayacaktır. Yani örnek olarak verdiğimiz suçta tutuklulukta azami süreler soruşturma evresinde 6 ay, kovuşturma evresinde ise soruşturma evresinde tutuklu olarak geçirilen süre dahil toplam 2 yildir.

\section{TUTUKLULUKTA AZAMİ SÜRENIN DOLMASININ HUKUKI SONUÇLARI}

1. Kanundaki azami sürenin dolmasıyla birlikte, tutukluluk hali kendiliğinden son bulur. ${ }^{25} \mathrm{Bu}$ ifadeyle kastettiğimiz, yargılama makamının azami sürenin dolduğuna ilişkin kararının kurucu değil, yalnızca durumu tesbit edici olduğudur.

${ }^{25}$ TOROSLU/FEYZİĞLUU: s. 227. 
2. Yargılama makamının söz konusu tesbit kararını vermesi bağlı yetkiye tabidir. Yani, bu durumda yargılama makamının tahliye kararı vermek konusunda herhangi bir takdir yetkisi yoktur; süre dolduğunda bu hususun tesbit edilmesi ve buna bağlı olarak tahliye kararı verilmesi zorunludur.

3. Söz konusu tesbit hükmünü ve tahliye kararını verecek olan yargılama makamı, soruşturmada sulh ceza hakimi, kovuşturmada henüz hüküm verilmedi ise mahkeme (heyet halinde görev yapan mahkemelerde heyetin o an toplanması mümkün değilse CMK md. 108 uyarınca mahkeme başkanı veya üyesi), istinaf yargılamasına başlanmışsa bölge adliye mahkemesi, dosya temyiz mahkemesindeyse Yargıtay'ın ilgili dairesi veya Ceza Genel Kurulu'dur (CMK md. 104/3).

4. Soruşturmada sulh ceza hakimince, kovuşturmada mahkemece (ilk derece mahkemesi ve bölge adliye mahkemesi) verilen tutuklamaya ilişkin bu kararlara karşı CMK md. 267 ve md. 268 uyarınca itiraz edilebilir.

5. Tutuklulukta azami sürenin dolduğuna (veya dolmadığına) ve bu nedenle şüphelinin/sanığın tahliyesine (veya süre dolmadığ 1 için tahliye edilmemesine) dair yargılama makamı kararlarına karşı, bu karar Yargıtay tarafından verilmediği sürece, kanun yararına bozma kanun yolu (CMK md. 309) açıktır.

6. Her ne kadar 4675 sayılı İnfaz Hakimliği Kanunu'nunda bu konuda açık bir düzenleme bulunmasa da tutuklulukta geçecek azami sürenin dolması halinde, söz konusu tesbit kararı, anılan Kanunun 4/2. maddesindeki yetki çerçevesinde infaz hakimliğince de verilebilmelidir. Zira kanundaki azami sürenin dolmasıyla birlikte, tutukluluk hali zaten kendiliğinden son bulmuştur. Bu durum bir an önce tesbit edilmeli ve tutuklu bir an öce özgürlüğüne kavuşturulmalıdır. Çünkü özgürlüğün 
birkaç saati bile değerlidir. ${ }^{26}$ Kaldı ki burada hakim işin esasına ilişkin herhangi bir inceleme ve değerlendirme yapmaksızın sadece basit bir matematiksel hesapla bu sonuca ulaşacaktır.

\section{SONUÇ YERINEE ÜÇ DİZE}

"Ben içeri düştüğümden beri güneşin etrafinda on kere döndü dünya Ona sorarsaniz: 'Lafi bile edilemez, mikroskopik bi zaman...' Bana sorarsanız: 'On senesi ömrümün...'”

\section{( Ben İçeri Düştüğ̈̈mden Beri, Nazım Hikmet)}

${ }^{26}$ FEYZİĞLU: “Tutukluluk...”, s. 1193. 


\section{KAYNAKÇA}

ANTOLISEI, Francesco: Manuale di diritto penale, parte speciale, vol. I, Milano 1999.

CENTEL, Nur: Ceza Muhakemesi Hukukunda Tutuklama ve Yakalama, İstanbul 1992.

CENTEL, Nur/ZAFER, Hamide: Ceza Muhakemesi Hukuku, İstanbul 2008.

FEYZİĞLLU, Metin: Ceza Muhakemesinde Vicdani Kanaat, Ankara 2002.

FEYZİĞLU, Metin: "Suçsuzluk Karinesi: Kavram Hakkında Genel Bilgiler ve Avrupa İnsan Hakları Sözleşmesi”, $A \ddot{U H F D, ~ y ı 1: ~ 1999, ~ c . ~}$ 48, sy. 1-4, ss. 135-163.

FEYZİĞLU, Metin: "5271 Sayılı Ceza Muhakemesi Kanunu Hakkında Bazı Tespit ve Değerlendirmeler”, TBBD, y1l: 2006, sy. 62, ss. 27-61.

FEYZİĞLU, Metin: "Tutuklamaya Dair Uygulamada Görülen Bazı Sorunlar, Tesbitler, Değerlendirmeler", (in) Prof. Dr. Ali Naim Inan'a Armağan, Ankara 2009, ss.1189-1193.

FEYZİĞLU, Metin: "Korkuya Sevk Etmemeli”, Cumhuriyet Gazetesi, 22.01.2009, s. 7.

FOSCHINI, Gaetano: Sistema del diritto processuale penale, vol. I, Milano 1956.

GAROFOLI, Vincenzo: Istituzioni di diritto processuale penale, Milano 2006.

HAKERİ, Hakan/ÜNVER, Yener: Ceza Muhakemesi Hukuku, Temel Bilgiler, Ankara 2008.

İNCİ, Z. Özen: Bir Koruma Tedbiri Olarak Türk Ceza Muhakemesi Hukukunda Tutuklama, Ankara 2008. 
KUNTER, Nurullah/YENISEY, Feridun/NUHOĞLU, Ayşe: Muhakeme Hukuku Dalı Olarak Ceza Muhakemesi Hukuku, İstanbul 2006.

NUHOĞLU; Ayşe: "Koruma Tedbiri Olarak Tutuklama", (in) Ceza Muhakemesi Kanunun 3. Yllı, İstanbul 2009, ss. 175-191.

ÖZGEN, Eralp: Ceza ve Ceza Muhakeme Hukuku Bilgisi, Eskişehir 1988.

ÖZTÜRK, Bahri/ERDEM, Mustafa Ruhan: Uygulamalı Ceza Muhakemesi Hukuku, Ankara 2007.

ÖZTÜRK, Bahri /ERDEM, Mustafa Ruhan /ÖZBEK, Veli Özer: Uygulamalı Ceza Muhakemesi Hukuku, Ankara 1999.

ÖZTÜRK, Bahri/TEZCAN, Mahmut/ERDEM, Mustafa Ruhan/SIRMA, Özge/SAYGILAR, Yasemin F. /ALAN, Esra: Nazari ve Uygulamalı Ceza Muhakemesi Hukuku, Ankara 2009.

ŞAHIN, Cumhur: Ceza Muhakemesi Hukuku, I, Ankara 2007.

ŞENTUNA, Mustafa Tarı: 5271 Sayılı Ceza Muhakemesi Kanununda Tutuklama ve Adli Kontrol, Ankara 2007.

TOROSLU, Nevzat: Cürümlerin Tasnifi Bakımından Suçun Hukuki Konusu, Ankara 1970.

TOROSLU, Nevzat/FEYZİĞLU, Metin: Ceza Muhakemesi Hukuku, Ankara 2009.

ÜNAL, Şeref: Avrupa Insan Hakları Sözleşmesi, Ankara 1995. 